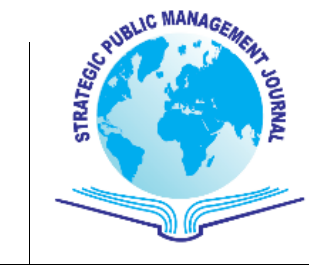

\section{Cumhurbaşkanlığı Kararnamesi Yetkisinin Amerikan Sistemi Üzerinden Karşılaştırmalı Analizi ${ }^{1}$}

\author{
A Comparative Analysis of the Presidential Decree Power \\ through the American System
}

Çağrı D. ÇOLAK ${ }^{2}$
Strategic Public Management Journal Volume 3, Special Issue, pp. 51-50 December 2017

DOI: $10.25069 /$ spmj.342107 Received: 11.10.2017 Accepted: 29.12.2017

(c) The Author(s) 2017

For reprints and permissions: http://dergipark.gov.tr/spmj

$\ddot{O} z$

Türk siyasal hayatında öteden beri var olan hükümet sistemi arayışı, 10 Aralık 2016 tarihli Anayasa Değişikliği Teklifi ile daha somut bir nitelik kazanmıştır. Söz konusu teklifle "Cumhurbaşkanlĭ̆ı Sistemi" adıyla birçok yönden başkanlık sistemine benzeyen bir model önerilmiş ve 16 Nisan 2017 tarihli halkoylamaslyla kabul edilmiştir. Modelde yer alan düzenlemeler kamuoyunda yoğun bir şekilde tartışılmıştır. Bu tartışmalarda öne çıkan konulardan biri Anayasanın 104. maddesine eklenen ve Cumhurbaşkanının yetkileri ve görevleri kısmında yer alan "Cumhurbaşkanı, yürütme yetkisine yönelik konularda, Cumhurbaşkanlı̆̆ı kararnamesi çıkarabilir” hükmüdür. Bu çalışmanın amacı, ülkeyi kararnamelerle yönetmek, meclisi etkisiz kılmak $v b$. argümanlarla tartışllan bu hükmü ABD'deki uygulamayla karşılaştırmalı bir biçimde incelemektir. Bu bağlamda ABD'de "executive order" adıyla anılan başkanlık kararnamelerinin yasama-yürütme ilişkileri çerçevesinde nasıl sistematize edildiği açılanmış ve sonrasında Türkiye için uygulanacak modelin ABD'deki ile benzer ve farklı yönleri ortaya konmuştur.

Anahtar Kelimeler: Cumhurbaşkanlı̆̆ı Sistemi, Başkanlık Sistemi, Cumhurbaşkanlı̆̆ı Kararnamesi

\title{
Abstract
}

The quest for a long-standing government system in Turkish political life has become more tangible with the Constitutional Amendment Proposal of December 10, 2016. The proposal has been offered with the so-called "Turkish Presidential System", which has many similarities with presidential systems and accepted with the referendum of April 16, 2017. The arrangements in the model are being discussed intensively in the public. One of the most prominent issues in these discussions is the provision of Article 104 of the Constitution, which is included in the authority and duties of the President of the Republic "The President can issue a presidential decree in matters related to executive power". The aim of this study is to examine this provision, which is debated with the arguments such as ruling the state with decrees and neutralizing the parliament, in comparison to U.S.A practices. In this context, it is explained how the presidential orders, which are referred to as "executive order" in the US, are systematized within the framework of legislative-executive relations, and later the similar and different aspects of the applied model for Turkey are asserted.

Key words: Turkish Presidential System, American Presidential System, Presidential Decree

1 Bu çalışma, yazarın 13-14 Nisan 2017 tarihleri arasında İstanbul'da düzenlenen III. Stratejik Kamu Yönetimi Sempozyumu'nda "2016 Anayasa Değişikliği Teklifinde Cumhurbaşkanlığı Kararnamesi: Amerikan Sistemi Üzerinden Bir Analiz" başlığıyla sunduğu bildirinin genişletilmiş ve gözden geçirilmiş halidir.

2 Arş. Gör., Karadeniz Teknik Üniversitesi, Sosyal Bilimler Enstitüsü, Kamu Yönetimi Anabilim Dalı, cagricolak61@ktu.edu.tr 


\section{GİRIŞ}

Cumhuriyet dönemi Türk Anayasa tarihi, kuvvetler birliğinden kuvvetlerin sert bir biçimde ayrılmasına doğru giden ya da yürütme organı kademeli bir biçimde güçlendirilen bir hükümet sistemi serüvenini yansıtmaktadır. Söz konusu tarihsel çerçevenin önde gelen anayasal çıktıları; 1921, 1924, 1961 ve 1982 Anayasalarıdır. Ayrıca 1971-1973 ve 2007 Anayasa Değişiklikleri bu serüvenin önemli dönüm noktaları olarak öne çıkmaktadır.

Teşkilat-1 Esasiye Kanunu olarak bilinen 1921 Anayasası, yukarıda ifade edilen tarihsel çerçevenin ilk adımını oluşturmaktadır. Yasama, yürütme ve yargı yetkilerinin tümünün Türkiye Büyük Millet Meclisi (TBMM)'nde toplandığ 1 bu anayasada "Meclis Hükümeti Sistemi" benimsenmiştir. Dolayısıyla hem kuvvetler birliği sağlanmış hem de bu birlik yasamayı güçlendirecek bir biçimde tesis edilmiştir. Ardından 1924 Anayasasında yine kuvvetlerin birliği ancak görevlerin ayrılığına dayanan, meclis hükümeti ve parlamenter sistemin birleşiminden oluşan karma bir hükümet sistemi geliştirilmiştir. Özetle, kuvvetler birliğine dayanan 1921 ve 1924 Anayasalarının yasama fonksiyonu ağır basmaktadır.

Kuvvetler ayrılığı ilkesinin Cumhuriyet tarihindeki ilk anayasal kaynağı, yasama yetkisinin TBMM çatısı altında "Millet Meclisi" ve "Cumhuriyet Senatosu" adlı iki meclise, yürütme yetkisinin ise Cumhurbaşkanı ve Bakanlar Kuruluna verildiği 1961 Anayasasıdır. Yürütmenin yasama içinden çıkması ve Cumhurbaşkanının yetkilerinin sembolik olması açısından 1961 Anayasası ile saf bir parlamenter sistem tasarlanmıştır. Ancak 12 Mart 1971 Askeri Muhtırası sonucunda gerçekleştirilen 1971-73 Anayasa Değişiklikleri ile 1961 Anayasasının özgürlükçü ve liberal yönleri kırpılıp yürütmenin güçlendirilmesine yönelik hamleler yapılmıştır. Ardından 1980 Askeri Darbesi sonucu yürürlüğe giren 1982 Anayasası ile "rasyonelleştirilmiş parlamentarizm" uygulamalarıyla yürütmeye verilen yetkiler artırılmıştır. Son olarak 2007 Anayasa Değişikliği ile getirilen "Cumhurbaşkanının halk tarafından seçilmesi” hükmü, mevcut parlamenter sistemi uygulamada yarı-başkanlık sistemine dönüştürmüştür.

1961 Anayasası ile yumuşak da olsa tesis edilen kuvvetler ayrılığı ilkesi, 1971-73 Anayasa Değişiklikleri, 1982 Anayasası ve 2007 Anayasa Değişiklikleri ile kademeli olarak sertleştirilmiş ve her bir sertleştirme hamlesi, başkanlık sistemi tartışmalarına yol açmıştır. Genellikle istikrar ve güçlü yürütme temaları çerçevesinde, Amerikan modeli örnek gösterilerek işlenen başkanlık sistemi tartışmaları, Kasım 2012'de Adalet ve Kalkınma Partisi (AKP)'nin TBMM Anayasa Uzlaşma Komisyonuna sunduğu teklifle daha farklı bir zemine (Türk Tipi Başkanlık) kaymıştır. Nitekim 10 Aralık 2016 tarihli Anayasa Değişikliği Teklifi ile 2012 yılında önerilen taslak, Türkiye’ye özgü başkanlık modelinin önerilmesi veya herhangi bir başkanlık modelinin olduğu gibi alınmaması yönünden paralellik arz etmektedir.

Öte yandan başkanlık sisteminin Amerikan modeli ekseninden çıkartılıp "Türk Tipi Başkanlık” adıyla Türk yönetsel ve politik kültürü çerçevesinde tasarlanması, kamuoyunda başkanlık sistemi ile ilgili yeni gündemlere kapı aralamıştır. Amerikan modeliyle Türkiye için önerilen başkanlık modeli arasındaki farklar tartışılmış, bazı kesimler başkanlık sisteminin en demokratik örneğinin Amerika Birleşik Devletleri (ABD)'nde bulunduğu ve başkanlık sistemini kendine özgü hale getiren birçok devletin otoriterleştiği argümanını savunmuştur.

Kamuoyunda "Cumhurbaşkanlığı sistemi” olarak ifade edilen Türk Tipi Başkanlık modeli önerisi, yasamayürütme ilişkilerinin içeriği ve Cumhurbaşkanının yetkileri bağlamında Amerikan Başkanlık sisteminden bazı konularda ayrılmaktadır. Karşılıklı feshin mümkün oluşu, yasama ve yürütme seçimlerinin eş zamanlı yapılışı ve Cumhurbaşkanının yetkileri, söz konusu farkların içerisinde öne çıkan başlıklar arasında yer almaktadır. $\mathrm{Bu}$ farklılıklar bağlamında tartışılan konulardan biri, Cumhurbaşkanının yetkileri ve görevlerinin düzenlendiği Anayasanın 104. maddesine eklenen "Cumhurbaşkanı, yürütme yetkisine yönelik konularda, Cumhurbaşkanlığı kararnamesi çıkarabilir" hükmüdür. ABD Anayasasında Başkana böyle bir yetkinin açık 
bir ifadeyle verilmemesi ve bu yetkinin Cumhurbaşkanına yasamanın alanına giren konularda düzenleyici işlem yapabilme firsatı vermesi, Cumhurbaşkanlığı kararnamesi uygulamasının eleştirilmesine yol açmıştır.

Çalışmanın amacı, ülkeyi kararnamelerle yönetmek ve böylelikle parlamentoyu etkisiz kılmak gibi iddialarla tartışılan bu yetkiyi ABD'deki “executive order” uygulamasıyla karşılaştırmalı bir biçimde incelemektir. İlk bölümde 10 Aralık 2016 tarihli Anayasa Değişikliği Teklifinin kamuoyundaki yansımaları ve referanduma sunulmak üzere parlamentoda kanunlaşması sürecine değinilmiştir. Ardından Cumhurbaşkanlığı kararnameleri ile düzenlenebilecek konulara anayasa değişiklik teklifi metninden atıflarla yer verilmiştir. Son olarak ABD'de "executive order" adıyla anılan başkanlık kararnamelerinin yasama-yürütme ilişkileri çerçevesinde nasıl sistematize edildiği açıklanmış ve Türkiye için uygulanacak modelin ABD'deki ile benzer ve farklı yönleri ortaya konmuştur.

\section{10 ARALIK 2016 TARİHLİ ANAYASA DEĞİŞİKLİĞİ TEKLİİ}

Türkiye'de hükümet sistemi tartışmalarının geçmişi 1960'lara kadar uzanmaktadır. Çeşitli nedenlerle bazı politikacılar tarafindan gündeme getirilen reform talepleri genellikle başkanlık sistemi ekseninde tartışılmıştır. Söz konusu reform arayışları uzun yıllar Türkiye'nin gündeminde yer alsa da, bu yöndeki adımların 12 Haziran 2011 seçimleri sonrasında somutlaşmaya başladığı görülmektedir. Bu dönemde TBMM çatısı altında bir "Anayasa Uzlaşma Komisyonu” kurulmuş ve başkanlık sistemi tartışmaları, yeni ve sivil bir anayasa oluşturma hedefi ile eşgüdümlü yaşanmıştır. Ancak komisyonun yeni anayasa oluşturma hedefi, Gezi Parkı şiddet olayları, 17-25 Aralık süreci, çeşitli örgütlerin gerçekleştirmiş olduğu terör saldırıları ve en önemlisi muhalefet partilerinin gereken desteği sağlamaması nedenleriyle sekteye uğramıştır.

Son elli yılda Alpaslan Türkeş, Süleyman Demirel, Turgut Özal ve Recep Tayyip Erdoğan gibi politikacılar tarafından zaman zaman gündeme getirilen başkanlık sistemi tartışmalarında 2012 yılı bir dönüm noktası niteliği taşımaktadır. Çünkü bu yıla kadarki başkanlık sistemi tartışmaları, politikacılar tarafından ortaya atılan cılız gündem önerileri olmanın ötesine geçememiştir. Ancak Kasım 2012'de AKP'nin Anayasa Uzlaşma Komisyonuna başkanlık sistemini içeren bir taslak metin önermesi, Türkiye'de bir siyasi partinin alternatif bir hükümet sistemini ayrıntılarıyla ortaya koyması açısından milat teşkil etmektedir (Çolak ve Uzun, 2017: 211).

Söz konusu taslağın diğer önemli özelliği, Türk anayasa literatürüne "Türk Tipi Başkanlık” kavramını hediye etmiş olmasıdır. Taslaktan önceki başkanlık sistemi tartışmaları genellikle Amerikan başkanlık modeli ekseninde yaşanmaktaydı. Nitekim başkanlık sistemini öneren birçok politikacı, argümanlarını ABD sisteminin özellikleriyle referanslandırmaktaydı. Ancak 2012'de ortaya çıkarılan taslak, Türk politik ve yönetsel kültüründen hareketle özgün bir hükümet modeli olarak tasarlanmıştır.

Gerek bir siyasi parti tarafından hazırlanıp komisyona sunulması, gerekse "Türk tipi Başkanlık” adıyla özgün bir model ortaya konulması, Türkiye'nin politik gündeminde hükümet modeline ilişkin tartışmaların ilk kez yüksek sesle tartışılmasıyla sonuçlanmıştır. Taslağın içinde yer alan maddeler, politikacılar arasında hararetli tartışmaların yaşanmasına yol açmıştır. Özbudun (2013: 205), bu durumun nedenini Türkiye'de hükümet sistemi tartışmalarının, rasyonel ve bilimsel olmaktan çok duygusal ve ideolojik çerçevede ele alınması, lehte ve aleyhte görüşlerin çok abartılı bir şekilde sunulması olarak ifade etmiştir. Erdoğan (2013: 547), AKP tarafından önerilen hükümet sistemini çoğulcu demokratik anlayışı zedeleyeceği endişesiyle eleştirmiştir. Teziç (2013: 367) ise taslağın, Başkana, üst düzey devlet görevlilerini TBMM onayı olmaksızın atama, TBMM denetimine bağlı olmaksızın kanun gücünde kararname çıkarma ve TBMM'yi fesih yetkisi veren maddelerinden hareketle modelin otoriterleşmeye yol açacağını dile getirmiştir. 
Kasım 2012'de komisyona sunulan taslak, her ne kadar kanunlaşmasa da başkanlık özelinde hükümet sistemleri konusunu Türkiye gündemine taşıması açısından büyük önem arz etmektedir. Bu bağlamda yapılan tartışmalar ve getirilen eleştiriler, 10 Aralık 2016 tarihinde AKP üyesi 316 milletvekilinin imzasıyla Meclis Başkanlığına sunulan ve 21 maddeden oluşan "Türkiye Cumhuriyeti Anayasasında Değişiklik Yapılması Hakkında Kanun Teklifi” başlıklı metnin olgunlaşmasında önemli rol oynamıştır³.

Akgün (2017: 6), bu durumun özellikle teklifin daha geniş kesimlerin Cumhurbaşkanı adayı gösterebilmesi, cezai sorumluluğun işletilmesinde daha uygulanabilir bir usulün getirilmesi, Meclisin geri gönderilen kanunu nitelikli çoğunluk yerine salt çoğunlukla kabul edebilmesi, Cumhurbaşkanı kararnamelerinin kanun karşısındaki ikincil konumunun güçlendirilmesi ve Hâkimler ve Savcılar Kurulu (HSK) üyelerinin seçimine ilişkin hükümlerinde göze çarptığını belirtmektedir.

Yukarıda sayılan hükümler dışında, 2012 Anayasa taslağı ile 2016 Anayasa değişiklik teklifi benzerlik arz etmektedir. İki metinde de aynı hükümet sistemi benimsenmiştir. Hatta 2012 anayasa taslağının, 2016 anayasa değişiklik teklifinin iskeletini oluşturduğunu söylemek iddialı bir açıklama olmayacaktır. Göze çarpan en belirgin fark, 2012'deki metinde Başkan olarak düzenlenen ifadenin 2016'da Cumhurbaşkanı olarak formüle edilmesidir.

Anayasa değişiklik teklifinin genel gerekçesinde şu ifadelere yer verilmiştir: "1961'den günümüze uzanan çizgide, parlamentonun seçtiği sembolik yetkileri olan 'bürokrat' cumhurbaşkanından, milletin doğrudan seçtiği geniş yetkileri bulunan 'siyasetçi' cumhurbaşkanı profiline geçiş yaşanmıştır. Hükümet sistemini bütüncül bir yaklaşımla ele almayı engelleyen sosyal ve siyasi şartlar ve gelişmeler, sonuçta bir sistem karmaşasına yol açmıştır. Sistemin işleyiş̧inde sorunlar doğurması kaçınılmaz olan bu karmaşanın aşılması hükümet sisteminde esaslı bir anayasa değişikliği zaruretini ortaya çıkartmıştır" (tbmm.gov.tr, 2016).

4 Ocak 2017'de komisyon sürecini tamamlayan ve 21 Ocak 2017'de Meclis Genel Kurulunda yapılan son oylama sonucu 339 evet oyu ile kabul edilen Anayasa değişiklik teklifi, 11 Şubat 2017'de Cumhurbaşkanı tarafından onaylanarak referanduma sunulmak üzere kanunlaştırılmıştır. 16 Nisan 2017 tarihli referandumda halkın önüne getirilen teklif, \%51,41 oranında "Evet" oyuyla kabul edilmiştir.

2017 Anayasa değişikliğine yöneltilen eleştirilerin birçoğu, 2012'de hazırlanan taslağa yöneltilen eleştirilerde olduğu gibi, sistemin özgün yanlarından yani Amerikan modeliyle farklarından kaynaklanmaktadır. Gözler (2017), Amerikan ve Türk Başkanlık sisteminin farklarını dokuz başlık altında toplamıştır:

- ABD’de Başkan, yasama organı tarafından görevden alınamaz; Türkiye'de önerilen sistemde alınabilir.

- ABD’de Başkan, yasama organını feshedemez; Türkiye'de önerilen sistemde ise (kendi seçimlerini de yenilemek şartıyla) feshedebilir.

- ABD’de Başkan Yardımcısı da halk tarafından seçilir; Türkiye'de ise Cumhurbaşkanı Yardımcısı veya Yardımcıları Cumhurbaşkanı tarafından atanır.

- ABD’de Bakanların atanması Senatonun onayına tabidir; Türkiye'de ise değildir.

— ABD'de Başkanın Yüksek Hâkim Atama Yetkisi, Senatonun onayına tabidir; Türkiye'de ise değildir.

3 TBMM'ye gönderildiğinde 21 maddeden oluşan taslak, daha sonra 18 maddeye indirilmiştir. Yedek vekilliği düzenleyen 78. madde; kamu tüzel kişiliğinin Cumhurbaşkanlığ kararnamesiyle kurulabilmesini düzenleyen 123. madde ve merkezi idare kapsamındaki kamu kurumlarının kuruluş, yetki, görev ve sorumluluklarının Cumhurbaşkanlığı kararnamesiyle belirlenmesini düzenleyen 126. maddedeki değişiklikler metinden çıkarılmıştır. 
- ABD’de Başkanın kamu görevlisi atama yetkisi, Senatonun onayına tabidir; Türkiye'de ise değildir.

- ABD'de Başkanın yaptığı uluslararası antlaşmaları onaylama yetkisi Senatonun 2/3 çoğunluğuna aittir; Türkiye'de ise aynı şart yoktur.

- ABD’de Başkanın her halükarda Kongrenin kabul edeceği bütçeye ihtiyacı vardır; Türkiye'de ise bütçenin kabul edilmemesi durumunda, Başkan eski bütçeyi enflasyon oranında artırarak vergi toplamaya ve harcama yapmaya devam edebilecektir.

— ABD’de Başkanın partisi ile ilişkisi gevşektir; Türkiye'de ise çok sıkı olma ihtimali vardır.

Karşılıklı fesih hükmünden hareketle sistemi bir nevi "başbakansız parlamenter sistem" olarak adlandıran Gözler (2016)'e göre, Cumhurbaşkanına verilen yetkiler şartsız ve sınırsız bir şekilde, herhangi bir denetime tabi olmaksızın verilmiştir. Anayasa değişiklik teklifini eleştirenler Cumhurbaşkanına 104. madde ile verilen bu yetkileri ABD Başkanı ile karşılaştırarak yorumlamış ve kararname çıkarma yetkisini de bu bağlamda değerlendirmiştir. Ancak sanılanın aksine, kararname çıkarma yetkisi, ABD modelinde olmamasına rağmen Türk Tipi Başkanlık çerçevesinde düzenlenen özgün bir hüküm değildir. Bu bağlamda ABD modeline geçmeden önce, Anayasa değişiklik teklifinde yer alan Cumhurbaşkanlığı modeline ve bu sistemde kararnamelerin hangi sınırlarla düzenlendiğine değinmekte fayda vardır.

\section{ANAYASA DEĞişiKLIĞIYYLE DÜZENLENEN YENI YETKİ: CUMHURBAŞKANLIĞI KARARNAMESI}

Cumhurbaşkanlığı sistemi olarak formüle edilen sistemin en önde gelen özelliği, yürütmedeki düalist yapıyı ortadan kaldırmasıdır. Başka bir deyişle, mevcut uygulamada Cumhurbaşkanı ve Bakanlar Kurulu tarafından paylaşılan yürütme mekanizmasının değişiklikle beraber yalnızca Cumhurbaşkanı tarafından temsil edilmesi öngörülmektedir. Dolayısıyla Başbakan ve Bakanlar Kurulunun yürütme adına sahip olduğu yetkiler Cumhurbaşkanına devredilmektedir. Bakanlar Kurulu tarafından TBMM'den alınan kanun hükmünde kararname çıarma yetkisi de bu kapsamda değerlendirilmektedir.

Kasım 2012'de Anayasa Uzlaşma Komisyonuna sunulan başkanlık sistemine ilişkin model önerisinin taslak metninde kararname yetkisi "başkanlık kararnamesi” adıyla düzenlenmişti. Bu metinde Başkana genel siyasetini yürütmede ihtiyaç duyduğu tüm konularda kararname çıkarabilme yetkisi tanınmış ve bu yetkiye üç farklı sınır getirilmiştir (Akgün, 2017):

— Kişi hak ve hürriyetleri ile siyasi hak ve hürriyetler kararname ile düzenlenemez.

— Kararname çıkarılabilmesi için kanunlarda o konuyu düzenleyen uygulanabilir açık hükümlerin bulunmamas1 gerekir.

- Kararnameler ile kanunlarda aynı konuda farklı hükümler bulunması halinde kanun hükümleri uygulanir.

İlk öneri kararnamelere getirilen sınırlamaların yeterli olmadığı gerekçesiyle birçok anayasa hukukçusu tarafından eleştirilmişti. Çünkü kararnamelerin kanun karşısındaki ikincil konumu sınırlamalarla yeterince vurgulanmamaktaydı (Akgün, 2017). Ayrıca taslakta kararname yetki sınırının oldukça geniş verildiği ve neredeyse Başkanın kanun çıkarma niteliğinde bir yetkiye sahip olduğu eleştirilmiştir. Özbudun (2013: 207), ABD'de bile Kongreyi by-pass edecek kararname çıkarma yetkisinin bulunmadığı, bu yetkinin başkanlık sisteminin otoriter temsilcileri olan Latin Amerika ülkelerinde "decrestismo" (kararname ile yönetim) olarak uygulandığını ifade etmiştir. Köker (2017), bu uygulamayla genel olarak Başkana asli yasama yetkisinin verildiğini ve bu yetkiye getirilen sınırlamaların yetersiz ve muğlak olduğunu belirtmiştir. Erdoğan (2013: 
546), Başkanın belli konularda açık hükümler bulunmadığından hareketle, bu alanı tamamen kararnamelerle düzenlemesi ve bunu alışkanlık haline getirmesinden duyduğu endişeyi dile getirmiştir.

Bu eleştirilere savunma getiren Burhan Kuzu, 2012'de vermiş olduğu bir röportajda kararnamelerle ilgili şu ifadelere yer vermiştir: “ABD'de Başkanın kararname çıkarma yetkisi bulunmadığı için Obama büyük sıkıntı çekiyor... Obama gece gündüz ağllyor, parlamentoya yalvarıyor. Sağlık reformunu çıkarmak için canı çıtı. Ancak üç aylık bütçelerle ülkeyi yönetebiliyor. ABD, bu sıkıntıları nasıl aşacağını tartışıyor. Başkana tanınan kararname çıkarma ve parlamentoyu feshetme yetkisi Güney Amerika ülkelerinde uygulanıyor" (www.aksam.com, 2017). Öte yandan, kararnameleri mevcut sistemdeki kanun hükmünde kararnamelerle karşılaştırıp yorumlayan Küçük (2016: 52), başkanlık kararnamesi yetkisine yönelik çerçevenin kanun hükmünde kararname yetkisine yönelik sinırlardan daha dar olduğunu, hatta olağanüstü hal dönemlerinde Anayasanın 15. maddesinde belirtilen çok az sayıdaki istisna dışında kanun hükmünde kararnamelerle düzenlenemeyecek hiçbir alanın olmadığını vurgulamıştır. Ancak kanun hükmünde kararnamelerin Meclisten alınacak yetkiyle çıkarıldığına, buna rağmen başkanlık kararnamelerinin bu açıdan Meclise bağımlı olmadığına değinmemiştir.

2017 Anayasa değişikliğinde Başkanlık sistemi nasıl "Cumhurbaşkanlığı sistemi” olarak formüle edildiyse, Başkanlık kararnameleri de aynı şekilde "Cumhurbaşkanlığı kararnamesi” kalıbıyla adlandırılmıştır. Ancak Cumhurbaşkanlığı kararnamesi, değişiklik öncesindeki anayasa metninde zaten mevcut olan bir düzenleyici işlemdir. Anayasal kaynağını 107. maddeden alan Cumhurbaşkanlığı kararnamesi ilk kez 18 Ağustos 1983 tarihinde düzenlenmiş ve böylelikle Cumhurbaşkanlığı kararnamesi adını taşıyan işlem hukukumuzda ilk kez uygulanmıştır (Taşdöğen, 2016: 940). Değişiklik öncesi mevzuatta yer alan Cumhurbaşkanlığı kararnameleri ile ancak 107. maddede belirlenen Cumhurbaşkanlığı Genel Sekreterliğinin kuruluş, teşkilat ve çalışma esasları ile personel atama işlemlerinin düzenlenmesi konularında işlem yapılabilmekteydi. Cumhurbaşkanlığı kararnamesi bu açıdan istisnai bir işlem türü olmakta ve Anayasanın 107. maddesinde belirtilenlerin dişındaki bir konunun Cumhurbaşkanlığı kararnamesiyle düzenlenmesine imkân bulunmamaktayd1. Özbudun (1993: 217)'a göre bu düzenlemenin amac1, Cumhurbaşkanlığı Genel Sekreterliğinin bir kanuna veya Bakanlar Kurulu kararnamesine ihtiyaç olmaksızın doğrudan doğruya cumhurbaşkanı tarafından düzenlenmesine imkân vermekti. Anayasa değişikliğiyle 104. maddeye eklenen ile değişiklik öncesindeki uygulamada 107. maddede yer alan Cumhurbaşkanlığı kararnamesi kalıpları aynı anlam ve sınırı içermemektedir.

Anayasa değişikliği metninde Cumhurbaşkanına kararname yetkisi veren ve bu yetkinin sınırlarını belirten hükümler şu şekildedir (6771 sayılı Kanun):

- Cumhurbaşkanı, yürütme yetkisine ilişkin konularda Cumhurbaşkanlığı kararnamesi çıkarabilir (Madde 104/17-1).

- Anayasanın ikinci kısmının birinci ve ikinci bölümlerinde yer alan temel haklar, kişi hakları ve ödevleriyle dördüncü bölümde yer alan siyasi haklar ve ödevler Cumhurbaşkanlı̆̆ı kararnamesiyle düzenlenemez (Madde 104/17-2).

- Anayasada münhasıran kanunla düzenlenmesi öngörülen konularda Cumhurbaşkanlı̆̆ kararnamesi çıkarılamaz (Madde 104/17-3).

- Kanunda açıkça düzenlenen konularda Cumhurbaşkanlığı kararnamesi çıkarılamaz (Madde 104/174). 
- Cumhurbaşkanlığı kararnamesi ile kanunlarda farklı hükümler bulunması halinde, kanun hükümleri uygulanir (Madde 104/17-5).

- Türkiye Büyük Millet Meclisinin ayn konuda kanun çıkarması durumunda, Cumhurbaşkanlığı kararnamesi hükümsüz hale gelir (Madde 104/17-6).

- Kararnameler ve yönetmelikler, yayımdan sonraki bir tarih belirlenmemişse, Resmi Gazetede yayımlandıkları gün yürürlüğe girer (Madde 104/19).

Yeni düzenlemenin 2012 taslağına kıyasla kanunların kararnameler karşısındaki üstünlügünü açık bir şekilde koruduğu ve bunu uygulamada da güçlendirdiği görülmektedir. Yeni metinde 2012 önerisinin aksine kararnamelerin yalnızca yürütme yetkisine dair konularda çıkarılabileceği ifade edilerek oluşması muhtemel bir belirsizliğin de önüne geçilmiştir (Akgün, 2017). Ayrıca ilk metne yöneltilen "kararnamelerin yetki sınırının belirsizliği"ne ilişkin eleştirileri ortadan kaldırmak amacıyla 2017'de kabul edilen metne iki yeni sınırlama eklenmiştir. İlki, anayasada münhasıran kanunla düzenlenmesi öngörülen konularda Cumhurbaşkanlığı kararnamesi çıkarılamayacak olmasıdır. Diğeri ise herhangi bir hususta çıkarılan Cumhurbaşkanlığı kararnamesinin TBMM'nin aynı konuda bir kanun kabul etmesi durumunda hükümsüz hale gelmesidir.

Cumhurbaşkanının kararname çıkaramayacağı alanlar 104. maddede belirtilmiş, çıkarabileceği alanlar ise konuyu ilgilendiren hükümlere eklenmiştir. Anayasa değişikliği metninin tümü tarandığında, Cumhurbaşkanlığı kararnamesiyle düzenlenebilecek alanlar aşağıda yer almaktadır (6771 sayılı Kanun):

- Cumhurbaşkanı, üst kademe kamu yöneticilerini atar, görevlerine son verir ve bunların atanmalarına ilişkin usul ve esasları Cumhurbaşkanlığı kararnamesiyle düzenler (Madde 104/9).

- Bakanlıkların kurulması, kaldırılması, görevleri ve yetkileri, teşkilat yapısı ile merkez ve taşra teşkilatlarının kurulması Cumhurbaşkanlığı kararnamesiyle düzenlenir (Madde 106/11).

- Devlet Denetleme Kurulunun işleyişi, üyelerinin görev süresi ve diğer özlük işleri, Cumhurbaşkanlı̆̆ kararnamesiyle düzenlenir (Madde 108/3).

- Milli Güvenlik Kurulu Genel Sekreterliğinin teşkilatı ve görevleri Cumhurbaşkanlığı kararnamesiyle düzenlenir (Madde 118/6).

- Kamu tüzel kişiliği, ancak kanunla veya Cumhurbaşkanlı̆̆ı kararnamesiyle kurulur ${ }^{4}$ (Madde 123/3).

Yukarıda yer alan hükümler, Anayasa metninde açık bir biçimde Cumhurbaşkanlığı kararnamesiyle düzenlenebilecek konuları göstermektedir. $\mathrm{Bu}$ hükümlere ilişkin konuların değişiklik öncesindeki uygulamada kanun hükmünde kararnamelerle düzenlenemediği, ancak ve ancak kanunla düzenlenebildiği göz önünde bulundurulduğunda, yasamanın ağırlığının azaltılması yönündeki eleştiriler anlam kazanmaktadır.

Öte yandan olağanüstü hal dönemlerinde çıkarılacak Cumhurbaşkanlığı kararnamelerinin yetki sınırları ve yürürlük durumlarına ilişsin hükümler 119. maddede düzenlenmiştir (6771 sayılı Kanun):

- Olağanüstü hallerde Cumhurbaşkanı, olağanüstü halin gerekli kıldığg konularda, 104. maddenin on yedinci fikrasının ikinci cümlesinde belirtilen sınırlamalara tabi olmaksızın Cumhurbaşkanlı̆̆

\footnotetext{
${ }^{4} \mathrm{Bu}$ değişiklik, TBMM'ye gönderilen ilk metinde Anayasa değişiklik teklifinin 14. maddesinde tek ve bağımsız düzenlenmişti. MHP'nin talebi üzerine 14. ve 15.maddeler metinden çıkarılmıştır. Ancak 14. madde metnin son halindeki toplu değişiklikleri düzenleyen 16. maddeye tekrar eklenmiştir.
} 
kararnamesi ç1karabilir (Madde 119/6-1). Kanun hükmündeki bu kararnameler Resmi Gazetede yayımlanır, aynı gün Meclis onayına sunulur (119/6-2).

- Savaş ve mücbir sebeplerle Türkiye Büyük Millet Meclisinin toplanamaması hali hariç olmak üzere; olağanüstü hal sırasında çıkarılan Cumhurbaşkanlığı kararnameleri üç ay içinde Türkiye Büyük Millet Meclisinde görüşülür ve karara bağlanır (Madde 119/7-1). Aksi halde olağanüstü hallerde çıkarılan Cumhurbaşkanlı̆̆ı kararnamesi kendiliğinden yürürlükten kalkar (119/7-2).

Cumhurbaşkanlığı kararnamelerinin yargısal denetimine ilişkin konular, "Yargı" erkine ilişkin bölümün maddelerinde aşağıdaki hükümler çerçevesinde düzenlenmiştir (6771 sayılı Kanun):

- Anayasa Mahkemesi, kanunların, Cumhurbaşkanlı̆̆ı kararnamelerinin ve Türkiye Büyük Millet Meclisi İçtüzügünün Anayasaya şekil ve esas bakımlarından uygunluğunu denetler ve bireysel başvuruları karara bağlar (Madde 148/1-1).

- Kanunların, Cumhurbaşkanlı̆̆g kararnamelerinin, Türkiye Büyük Millet Meclisi İçtüzüğünün veya bunların belirli madde ve hükümlerinin şekil ve esas bakımından Anayasaya aykırılığı iddiasıyla Anayasa Mahkemesinde doğrudan doğruya iptal davası açabilme hakkı, Cumhurbaşkanına, Türkiye Büyük Millet Meclisinde en fazla üyeye sahip iki siyasi parti grubuna ve üye tam sayısının en az beşte biri tutarındaki üyelere aittir (Madde 150).

- Anayasa Mahkemesinde doğrudan doğruya iptal davası açma hakkı, iptali istenen kanun, Cumhurbaşkanlı̆̆ kararnamesi veya içtüzüğün Resmi Gazetede yayımlanmasından başlayarak altmış gün sonra düşer (Madde 151).

- Bir davaya bakmakta olan mahkeme, uygulanacak bir kanun veya Cumhurbaşkanlığı kararnamesinin hükümlerini Anayasaya aykırı görürse veya taraflardan birinin ileri sürdügü anayasaya aykırılık iddiasının ciddi olduğu kanısına varırsa, Anayasa Mahkemesinin bu konuda vereceği karara kadar davayı geri bırakır (Madde 152/1).

- Kanun, Cumhurbaşkanliğı kararnamesi veya Türkiye Büyük Millet Meclisi İçtüzüğü ya da bunların hükümleri, iptal kararlarının Resmi Gazetede yayımlandığı tarihte yürürlükten kalkar (Madde 153/31). Gereken hallerde Anayasa Mahkemesi iptal hükmünün yürürlüğe gireceği tarihi ayrıca kararlaştırabilir (153/3-2). Bu tarih, kararın Resmi Gazetede yayımlandığı günden başlayarak bir yılı geçemez (153/3-3).

Yukarıdaki hükümler incelendiğinde Cumhurbaşkanlığı kararnamelerinin sınır ve denetim mekanizmalarının 2012'deki taslağa göre netleştiği görülmektedir. Kararnamelerle düzenlenemeyecek alanlar daha açık bir şekilde belirtilmiş ve kanun ile kararname arasında yaşanması muhtemel çatışmalara yönelik kanunu önceleyen net hükümler metne eklenmiştir. Ayrıca kararnamelerin yargısal denetiminden Anayasa Mahkemesi sorumlu tutulmuştur. Ancak bu güncellemeler, anayasa hukukçularının tümünü, cumhurbaşkanlığı kararnamesi yetkisinin genel yetki durumuna yol açmayacağına ikna etmekte yeterli olamamıştır. Örneğin, Can (2017), kararnamelerin, kanunlarla açıkça düzenleneceği belirtilen konular dışındaki her alanı düzenleyebileceğini ve bu nedenle yasama konusunda neredeyse genel yetki durumuna yol açacağını ifade etmiştir. Meclisin kararnameyi geçersiz kılmasının tek yolunun ilgili alanda kanun çıkarılması olduğunu dile getiren Can (2017), Cumhurbaşkanının kendi partisi ve Meclis çoğunluğunu kontrol etme imkânına sahip olduğu sürece, Meclisin yasa çıkarmasını engelleme gücüne sahip olabileceğini ve böylelikle tüm ülkenin yalnızca kararnamelerle yönetilmesi riskinin doğacağını iddia etmektedir.

Cumhurbaşkanlığı kararnamesiyle yasamaya ilişkin yetkilerin kullanılacağı ve Meclisin etkisizleştirileceğine ilişkin argümanlara karşı genellikle "Meclisi kanun yapmaya zorlamak" savunması getirilmiştir. Kuzu (2017: 
173), anayasa değişikliğiyle yürütmenin yasama yetkilerini kullanması veya bu yetkilere karışmasının amaçlanmadığını, yalnızca Meclisin kanun yapmaya zorlandığını belirtmiştir. Bununla kast edilen, Meclisle Cumhurbaşkanı arasında görüş ayrılığı olması durumunda ara formül olarak Cumhurbaşkanının kararnameyle düzenleme yapması, Meclisin de bu kararnamenin düşmesi için kanun çıkarmasıdır.

AKP'nin Anayasa Uzlaşma Komisyonuna 2012 yılında sunduğu taslakta da yer alan başkanlık kararnamesi düzenlemesi, çeşitli kesimler tarafından ABD'de böyle bir uygulamanın olmamasından hareketle eleştirilmişti. O dönem, eleştirilere savunma getiren TBMM Anayasa Komisyonu Başkanı Prof. Dr. Burhan Kuzu, 2012'de vermiş olduğu bir röportaj esnasında şu ifadeleri kullanmıştır: “Evet doğrudur, $A B D$ 'de Başkanın kararname çıkarma yetkisi yok. Modelimiz ABD sistemindeki tıkanıklıklara karşı önerdiğimiz model. Öyle ya parlamento görevini yapmaz, yasa çıkarmazsa Başkanın oturup ă̆layacak hali yok" (www.aksam.com, 2017).

Kuzu, 2012'de ABD’de Başkanın kararname yetkisinin olmadığını dile getirse de, dört yıl sonra, başkanlık kararnamesi uygulamasının tüm Başkanlık modellerinde mevcut olduğunu söylemiş ve bunu bir örnekle açıklamıştır: "ABD Başkanı Barack Obama başkanlı̆̆ı döneminde 276 adet Başkanlık kararnamesi çıkarmıştır. Keza, Donald Trump da göreve başlar başlamaz onlarca kararname yayımlamıştır” (Kuzu, 2017: 211). Aynı şekilde TBMM Anayasa Komisyonu Başkanı Prof. Dr. Mustafa Şentop, 2016 yılında vermiş olduğu bir röportajda şu ifadeleri kullanmıştır: “ABD'de de bu hak var. Obama bugüne kadar 276 kararname çıkardı. Hatta orada başkanlar kararnameyle kanunları değiştirebiliyor. Örneğin Obama, silahlanma ile ilgili konuda kongrenin çıkarmadığı bir kararname çıkardı. Türkiye’de bunu sınırladık. ABD Başkanı'na verilen yetkiden daha az yetki veriyoruz" (www.haberturk.com, 2017).

Görüldüğü üzere, Cumhurbaşkanllğı kararnamesi düzenlemesine ilişkin savunma ve eleştiriler, genellikle ABD modelinden hareketle getirilmektedir. Düzenlemeyi eleştirenler, Başkanlık kararnamesi uygulamasının yalnızca antidemokratik başkanlık sistemlerinde mevcut olduğunu, bununla birlikte ABD'de böyle bir uygulamanın söz konusu olmadığını belirtmiştir. Savunanlar ise kararname uygulamasının ABD'de mevcut olduğunu ve Başkanın bu yetkisiyle Kongreyi kanun yapmaya zorladığını ifade etmişlerdir. Bu bağlamda, ABD'de başkanlık kararnamesi uygulamasının ortaya çıkışı, niteliği, kapsamı, sınırları ve denetimi önem kazanmaktadır.

\section{AMERIKAN BAŞKANLIK SISTEMINDE KARARNAME: "EXECUTIVE ORDER"}

Anayasa hukuku literatüründe genellikle Başkanın kanun hükmünde kararname yayımlama yetkisinin olmadığına dair bir kanaat hâkimdir. Her ne kadar birçok Latin Amerika ülkesinde bu yetki anayasada belirlenmiş istisnai haller çerçevesinde mevcut olsa da, başkanlık sisteminin anavatanı ABD'de, Başkanın kanun hükmünde kararname yayımlama yetkisinin olmadığı kabul edilmektedir (Bozlağan, 2016: 57). Nitekim ABD Anayasası incelendiğinde Başkanın kanun hükmünde bir kararname çıkarma yetkisinin olduğuna dair açık bir ifadeye rastlanmamaktadır. Ancak mevcut Başkan Donald Trump, göreve başladığı 20 Ocak 2017'den 20 Eylül 2017'ye kadar (dokuz aylık sürede) 86 adet kararname yayımlamıştır. Önceki başkanların görev süreleri boyunca yayımladığı kararname sayıları ve bir seneye düşen kararname ortalamaları Tablo 1'de yer almaktadır.

1793 'te ilk ABD Başkanı George Washington, Fransa ile İngiltere arasındaki savaşta Amerikan tarafsızlığını ilan eden bir kararname yayımlamıştır (Pious, 1979: 51). Bu, bir Başkanın politika hedeflerini gerçekleştirmek için yayımladığı son kararname olmamış ve Abraham Lincoln'ün ilk numaralandırılmış kararnameyi imzalamasından bugüne ABD'de Başkanlar 13.000'den fazla kararname yayımlamıştır (Deering ve Maltzman, 1999: 767). Lincoln'den önce numaralandırılmayan kararnamelerle birlikte bu rakam yaklaşık 15.500'e yükselmektedir. 
Tablo 1. ABD Başkanlarının Görev Sürelerinde Yayımladıkları Kararname Sayıları ve Bir Seneye Düşen Kararname Ortalamaları

\begin{tabular}{|l|l|l|l|l|l|l|l|}
\hline \multicolumn{1}{|c|}{ Başkan } & $\begin{array}{l}\text { Görev } \\
\text { Süresi }\end{array}$ & Adet & Ort. & \multicolumn{1}{|c|}{ Başkan } & $\begin{array}{c}\text { Görev } \\
\text { Süresi }\end{array}$ & Adet & Ort. \\
\hline G. Washington & 7,95 & 8 & 1,01 & B. Harrison & 4,00 & 143 & 35,75 \\
\hline J. Adams & 4,00 & 1 & 0,25 & G. Cleveland II & 4,00 & 140 & 35,00 \\
\hline T. Jefferson & 8,00 & 4 & 0,50 & W. McKinley & 4,53 & 185 & 40,84 \\
\hline J. Madison & 8,00 & 1 & 0,13 & T. Roosevelt & 7,47 & 1081 & 144,71 \\
\hline J. Monroe & 8,00 & 1 & 0,13 & W.H. Taft & 4,00 & 724 & 181,00 \\
\hline J.Q. Adams & 4,00 & 3 & 0,75 & W. Wilson & 8,00 & 1803 & 225,38 \\
\hline A. Jackson & 8,00 & 12 & 1,50 & W.G. Harding & 2,41 & 522 & 216,60 \\
\hline M.V. Buren & 4,00 & 10 & 2,50 & C. Coolidge & 5,59 & 1203 & 215,21 \\
\hline W.H. Harrison & 0,08 & 0 & 0,00 & H. Hoover & 4,00 & 968 & 242,00 \\
\hline J. Tyler & 3,92 & 17 & 4,34 & F.D. Roosevelt & 12,11 & 3728 & 307,84 \\
\hline J.K. Polk & 4,00 & 18 & 4,50 & H.S. Truman & 7,77 & 907 & 116,73 \\
\hline Z. Taylor & 1,34 & 5 & 3,73 & D.D. Eisenhower & 8,00 & 484 & 60,50 \\
\hline M. Fillmore & 2,66 & 12 & 4,51 & J.F. Kennedy & 2,84 & 214 & 75,35 \\
\hline F. Pierce & 4,00 & 35 & 8,75 & L.B. Johnson & 5,16 & 325 & 62,98 \\
\hline J. Buchanan & 4,00 & 16 & 4,00 & R. Nixon & 5,56 & 346 & 62,23 \\
\hline A. Lincoln & 4,11 & 48 & 11,68 & G. Ford & 2,45 & 169 & 68,98 \\
\hline A. Johnson & 3,89 & 79 & 20,31 & J. Carter & 4,00 & 320 & 80,00 \\
\hline U.S. Grant & 8,00 & 217 & 27,13 & R. Reagan & 8,00 & 381 & 47,63 \\
\hline R.B. Hayes & 4,00 & 92 & 23,00 & G.H.W. Bush & 4,00 & 166 & 41,50 \\
\hline J.A. Garfield & 0,54 & 6 & 11,11 & B. Clinton & 8,00 & 364 & 45,50 \\
\hline C.A. Arthur & 3,46 & 96 & 27,75 & G.W. Bush & 8,00 & 291 & 36,38 \\
\hline G. Cleveland I & 4,00 & 113 & 28,25 & B. Obama & 8,00 & 276 & 34,50 \\
\hline
\end{tabular}

Kaynak: (Contrubis, 1999; www.presidency.ucsb.edu, 2017)

Rakamlardan da anlaşılacağı üzere, ABD'de Başkanların yasama fonksiyonu niteliğinde, tek taraflı ve dolaysız yapabildikleri, genel ve kişilik-dışı kurallar koyma ve düzenleme yetkileri bulunmaktadır (Nomer, 2013; Gözler, 2016). Bu yetki Anayasada açık bir şekilde yer almasa da genellikle bu yetkinin Anayasanın 2. maddesinden kaynaklandığ1 kabul edilmektedir (Contrubis, 1999: 23). ABD Anayasasında yürütme erkinin düzenlendiği 2. madde şu ifadeleri içermektedir: "Yürütme yetkisi, Amerika Birleşik Devletleri Başkanına verilecektir (2/1)... Başkan, Birleşik Devletler Kara ve Deniz Ordularının Başkomutanı olacaktır (2/2)... Başkan, yasalara sadık kalarak yönetmeye özen gösterecektir (2/3)" (The Constitution of USA). Başkanın bu yetkisinin anayasada açık bir şekilde yer almamasına rağmen kullanılması, onun bir nevi "anayasal teamül”" niteliğinde olduğunu ortaya koymaktadır (Gözler, 2016: 40).

"Executive order" olarak ifade edilen bu yetki, "başkanlı emri" veya "yürütme emri" anlamına gelmektedir. Özellikle güçlü Başkanlar, Anayasanın 2. maddesindeki ifadeleri, yetkilerini büyük bir güç kaynağı şeklinde genişletmek için kullanmışlardır. George Washington, Thomas Jefferson, Andrew Jackson, Abraham Lincoln, Theodore Roosevelt, Woodrow Wilson, Franklin D. Roosevelt ve George W. Bush söz konusu güçlü başkanlar arasında yer almaktadır. Örneğin, Washington ABD tarihinin ilk kararnamesiyle Başkanın dış 
ilişkilerde liderlik rolü üstlenmesini sağlamış; Lincoln ise İç Savaş (1861-1865) döneminde köleleri özgürlüğe kavuşturmak için bu maddeyi dayanak göstererek geniş yetkiler kullanmıştır (Peltason, 2017).

Başkanlık kararnameleri, Başkanın anayasal otoritesine dayandığı sürece kanun hükmünde bir emir niteliği taşımaktadır (Fisher, 1991: 109). Kararnameler, yürütme organlarına yönelik, federal hükümet dâhilindeki işleyişi kolaylaştırmak için çıkarılmaktadır. Başkanın kararname çıkarabilmesi için Kongreden yetki almasına gerek yoktur. Ayrıca kararnameler onay için Kongreye sunulmazlar. Başkanlar bu kararnamelerle önceden kanunla düzenlenmemiş bir alanı düzenleyebilmekte, hatta mevcut bir kanunda değişiklik yapabilmektedir (Gözler, 2016: 39). Örneğin, Trump, göreve başlar başlamaz, Obama döneminde çıkarılan sağlık ve iklim planına ilişkin iki kanunu kararnameyle iptal etmiştir. Ayrıca Başkanlık kararnameleri, bir kanunun uygulanmasını göstermek amacıyla veya kanunun bir hükmüne dayanılarak çıkarılabileceği gibi, mevzuat dayanağı olmadan tamamen bağımsız olarak da çıkarılabilmektedir (Nomer, 2013: 76). Ancak bunlar Kongrenin kararnameler üzerinde denetimi olmadığı anlamına gelmemektedir.

ABD'de Kongre, çıkaracağı kanuni düzenlemelerle, uygun bulmadığı başkanlık kararnamelerini geçersiz kılma imkânına sahiptir (Alkan, 2013: 779). Kongre, konuyla ilgili kanun çıkarmak yoluyla başkanlık kararnamesini iptal edebilmektedir (Contrubis, 1999: 24). Kongre eğer mevzuatla bir kararnameyi iptal ederse, Başkanın mesleki itibarı ciddi derecede hasar görebilmekte ve Başkanın bu sabıkası gelecekte yönetsel düzenleme yapmasını engelleyebilmektedir (Deering ve Maltzman, 1999: 779). Kongre tarafından çıkarılan bir kanunla Başkanlık kararnamesinin iptali, özellikle son zamanlarda nispeten nadir görülmektedir. Bugüne kadar çıkarılan başkanlık kararnamelerinin \% 4'ten azının Kongre tarafından değiştirilmesi bu durumu kanitlar niteliktedir (Chu ve Garvey, 2014).

Başkanlar, Kongreyi kanun yapmaya zorlamak için bir araç olarak kararnamelere başvurabilmektedir. Örneğin, 2014'te, yıllardır kapsamlı göçmenlik reformu yasasını geçirmeyen ABD Kongresini beklemekten vazgeçen Obama, milyonlarca kaçak göçmeni kısmen rahatlatacak bir Başkanlık kararnamesi yayımlamıştır. Cumhuriyetçilerin, kendisine yönelttiği anayasal yetki sınırını aştığı iddialarına ise tek yanıt vermiştir: "Yasa çıkarın" (amerikabulteni.com, 2017).

Başkanlık kararnameleri, Kongrenin onayına tabi tutulmamaları ve ancak Kongre tarafından çıkarılacak bir kanunla yürürlükten kalkabilmeleri bağlamında, yasama-yürütme ilişkilerinin gerilmesine yol açabilmektedir. Bazı Başkanlar, bu yetkiyi Kongreye rağmen hatta Kongreyi by-pass etmek için kullanmaktadır. Bu durum kararnamelerin geniş politik etkilere yol açabileceğini ortaya koymaktadır. Eisenhower'ın devlet okullarında ayrımcılığı kaldıran ve Roosevelt'in 1942 yılında bazı bölgelerin askeri bölge ilan edilmesine yönelik kararnameleri bu kapsamda değerlendirilebilir. Roosevelt'in söz konusu kararnamesi aracılı̆̆ıyla 70.000'in üzerinde Japon asıllı Amerikalı evlerinden alınmış ve askeri kamplarda toplanmıştır (Cengiz, 2017).

ABD Başkanları, kararnameleri, stratejik hareket edebilmek, politik hedeflerini etkili ve alternatif manevralarla takip edebilmek, Kongreyi by-pass edebilmek, acil durumlarda güçlerini kullanabilmek, yönetsel süreçler üzerindeki kontrollerini güçlendirebilmek ve önemli sembolik duruşlarını vurgulayabilmek amaçlarıyla kullanmaktadırlar (Krause ve Cohen, 1997; Mayer, 1999). Başkanlar, bu amaçlarına ulaşmak ve politika statüsünde önemli değişiklikler yapmak için kullanılabilecek bir araç olarak sıklıkla kararnamelere başvurmuşlardır (Ragsdale ve Theis, 1997). Böylelikle Başkanlığı uygun gördükleri şekilde örgütlemiş, yeni kamu kurumları yaratıp onları yeniden organize etmiş ve bu kurumlar arasında koordineyi sağlamışlardır (Moe, 1993: 366). Son yıllarda Başkanların; çevre, iş vb. alanlarda girişimleri desteklemek, güvenlik, sağlık ve ürün güvenliğini sağlamak gibi toplumsal konularda düzenleyici işlemler yapma yetkisini daha s1k kullandığı görülmektedir (Bradley ve Posner, 2006: 3).

ABD anayasal sisteminde Başkanlık kararnamelerini değiştirmek veya yürürlükten kaldırmanın tek yolu Kongrenin denetimi değildir. Kararnameler Kongre denetimine ek olarak ayrıca yargısal denetime de tabidir. Federal Yüksek Mahkeme, Başkanın düzenleyici işlemlerini kontrol edebilmektedir (Bruff, 1979: 508). 
Örneğin, Trump'ın Müslüman 7 ülkenin vatandaşlarına yönelik vize yasağını içeren kararnamesi, Federal Mahkeme tarafından durdurulmuştur.

Bir Başkanlık kararnamesini değiştirme veya yürürlükten kaldırmanın bir başka yöntemi de o konuya yönelik yeni bir kararnamenin yayımlanmasıdır (Contrubis, 1999: 19). Dolayısıyla ABD uygulamasında kararnameler yasama, yürütme ve yargı organlarının her biri açısından denetime tabidir. Yasama denetiminde Kongre konuyla ilgili yeni bir kanun çıkarır; yürütme denetiminde Başkan konuyla ilgili yeni bir kararname yayımlar; yargı denetiminde ise Federal Yüksek Mahkeme kararnameyi ya durdurur ya da iptal eder.

ABD'de Başkanlık kararnamelerinin incelendiği çalışmalardan elde edilen bulgular aşağıda özetlenmiştir (Mayer, 1999; Contrubis, 1999; Deering ve Maltzman 1999; Krause ve Cohen, 1997; Shull, 1997):

- Başkanlar, partilerinin Kongrede çoğunluğu elinde bulundurması durumunda daha fazla kararname yayımlamaktadırlar;

— Başkanlar, halk desteği düştükçe daha fazla kararname yayımlamaktadırlar;

— Başkanlar, kararnameleri genellikle görevlerinin ilk ve son yıllarında daha sık çıkarmaktadırlar;

- Yeniden seçim kampanyası yürüten Başkanlar, diğerlerine oranla daha çok kararname yayımlamaktadırlar;

— Başkanlar, popülariteleri düştükçe daha fazla kararname yayımlama eğilimi gösterirler;

- Demokrat Başkanlar, Cumhuriyetçi Başkanlara nazaran daha fazla kararname yayımlamaktadırlar;

— Başkanlık kararnamelerinin sıklığı, Başkanın politik ortamına göre değişmektedir.

Özetle, ABD sisteminde Başkana kanun hükmünde kararname yetkisinin tanınmadığına yönelik iddialar doğruyu yansıtmamaktadır. Kararname uygulamasının kaynağını Anayasadan açık bir şekilde almaması, böyle bir uygulamanın mevcut olmadığı sonucunu doğurmamaktadır. ABD Anayasası 7 maddeden oluşan çerçeve bir anayasadır. Bu bağlamda Türk Anayasalarından ayrılmaktadır. ABD'de Başkana tanınan her türlü yetki dayanağını Anayasanın 2. maddesinden almaktadır. Kararname yetkisi de bu bağlamda değerlendirilmektedir. ABD tarihinde göreve gelen 45 Başkandan yalnızca bir tanesi ${ }^{5}$ kararname yayımlamamıştır. Öte yandan, kararnamelerin kapsam ve sınırları belirsizdir. Başkan kararname ile kanunu bile değiştirebilmektedir. Ancak hem Kongre hem de Federal Yüksek Mahkeme tarafindan denetlenmektedir. Kongre, Başkanlık kararnameleri üzerindeki denetimini yalnızca o konuyla ilgili kanun çıkarıp kararnamenin iptal olmasına yol açarak sağlayabilir. Federal Yüksek Mahkeme ise kararnamelerin anayasaya uygunluğunu denetlemektedir.

\section{SONUÇ}

6771 Sayılı Türkiye Cumhuriyeti Anayasasında Değişiklik Yapılmasına Dair Kanun ile referanduma sunulmak üzere kanunlaştırılan ve 16 Nisan 2017 tarihli referandumda kabul edilen Anayasa değişikliği metninde Cumhurbaşkanına birtakım yetkiler verilmiştir. Anayasanın 104. maddesinde düzenlenen bu yetkiler arasında Cumhurbaşkanlığı kararnamesi çıkarma yetkisi de yer almaktadır. Söz konusu yetki, kamuoyunda, otoriterleşme tehlikesi, kararnamelerle yönetim, parlamentonun işlevsizleştirilmesi vb. argümanlarla tartışılmış ve tartışılmaya da devam etmektedir.

${ }^{5} 1841$ yılında göreve gelen ve görevi boyunca Başkanlık kararnamesi yayımlamayan tek Başkan olan William Henry Harrison, 31 günlük görev süresiyle ABD tarihinin en kısa süreli Başkanıdır. Kararname yayımlamamasının ardında yatan neden, görev süresinin kısa oluşuyla izah edilebilir. 
ABD, Başkanlık sisteminin anavatanı ve en demokratik uygulayıcısı olarak kabul edilmektedir. Bu bağlamda, Anayasa değişiklik metnindeki Cumhurbaşkanlığı kararnamesine ilişkin hükümlerin, ABD'de uygulanan kararname yetkisiyle karşılaştırılması ve bu iki modelin benzer ve farklı yanlarının ortaya konulması önem kazanmaktadır.

İlk olarak, Başkana tanınan kararname yetkisinin her iki ülkede de mevcut olduğunu belirtmek gerekmektedir. Ancak bu yetkilerin anayasal dayanağı konusunda iki model farklılık arz etmektedir. ABD'de Başkanın kararname yetkisi açık bir şekilde yer almamakta, anayasal teamül olarak kabul edilmektedir. Türkiye için uygulanacak modelde ise bu yetki Anayasanın 104. maddesinde "Cumhurbaşkanının yetkileri ve görevleri” başlığını taşıyan kısmında açık bir şekilde yer almaktadır: "Cumhurbaşkanı, yürütme yetkisine yönelik konularda, Cumhurbaşkanlı̆̆ kararnamesi çıkarabilir." İki model arasındaki diğer bir fark, bu düzenleyici işlemlere verilen isimlerde göze çarpmaktadır. Türk Tipi Başkanlıkta "Cumhurbaşkanlı̆̆l kararnamesi" ismi kullanılmaktadır. ABD'de ise bu işleme başkanlık kararnamesi anlamına gelen "presidential decree" değil, "başkanlık veya yürütme emri”" anlamına gelen "executive order" denmektedir.

Ayrıca ABD'de söz konusu yetkinin kapsam ve sınırları açık bir şekilde düzenlenmemiştir. Hâlbuki Türk tipi Başkanlık modelinde, Anayasanın 104. maddesinde Cumhurbaşkanlı̆̆ 1 kararnamesiyle hangi alanların düzenlenemeyeceği net bir şekilde yer almaktadır: "Anayasanın ikinci kısmının birinci ve ikinci bölümlerinde yer alan temel haklar, kişi hakları ve ödevleriyle dördüncü bölümde yer alan siyasi haklar ve ödevler Cumhurbaşkanlı̆̆ı kararnamesiyle düzenlenemez."

Diğer yandan Türk modelinde kararnamelerin kanun karşısındaki konumu açık bir şekilde belirtilmektedir: "Anayasada münhasıran kanunla düzenlenmesi öngörülen ve kanunda açıkça düzenlenen konularda Cumhurbaşkanlığı kararnamesi çıkarılamaz. Cumhurbaşkanlığı kararnamesi ile kanunlarda farklı hükümler bulunması halinde, kanun hükümleri uygulanır." ABD modelinde ise Başkanların kararname ile kanunu kaldırabildiklerine yönelik birçok örnek bulunmaktadır. Ancak bu durum Türkiye'deki anayasal hükümler çerçevesinde mümkün gözükmemektedir.

Kararnamelerinin denetiminde her iki model benzerlik göstermektedir. İki modelde de kararnameler yasama ve yarg1 tarafından denetlenebilmektedir. İki modelde de yayımlanan kararnameler yasama organın onayına tabi tutulmaz, ancak yasama organı istemediği bir kararnameyi o konuyla ilgili yeni bir kanun çıarmak suretiyle iptal edebilir. Anayasa değişikliği metninde bu hüküm şu şekilde ifade edilmektedir: "Türkiye Büyük Millet Meclisinin aynı konuda kanun çıkarması durumunda, Cumhurbaşkanlı̆̆ kararnamesi hükümsüz hale gelir." Son olarak, kararnamelerin yargısal denetimi her iki ülkedeki yüksek mahkemeler (ABD - Federal Yüksek Mahkeme; Türkiye - Anayasa Mahkemesi) tarafından yapılmaktadır. Türk Tipi Başkanlıkta kararnamelerin yargısal denetimi Anayasanın 148. maddesindeki hükümler çerçevesinde düzenlenmiştir.

ABD Anayasası "çerçeve" bir anayasa olduğu için kararnamelere ilişkin hükümler net ve yazılı değildir. Kararnameler, bir anayasal teamül niteliği taşımaktadır. Ancak ABD uygulamasından hareketle ulaşılan veriler 1şığında, ABD'de Başkanların kararname çıkarma yetkisinin, Türkiye'de Anayasa değişikliği metninde yer alan hükümlere nazaran daha sınırsız olduğu sonucuna ulaşılabilir. 


\section{KAYNAKÇA}

6771 Sayılı Türkiye Cumhuriyeti Anayasasında Değişiklik Yapılmasına Dair Kanun, Resmi Gazete, Tarih: 11 Şubat 2017, Sayı: 29976.

Akgün, M. H. (2017), "Başkanlıktan Cumhurbaşkanlığı Sistemine: 2012 ve 2016 AK Parti Anayasa Önerileri”, Seta Perspektif, S.163, ss. 1-6.

Alkan, H. (2013), "Karşılaştırmalı Başkanlık Sistemleri: Latin Amerika ve Sovyet Sonrası Örnekler Üzerine Bir İnceleme”, Yeni Türkiye Dergisi, C.9, S.51, ss. 779-789.

Bradley, C. A. and Posner, E. A. (2006), "Presidential Signing Statements and Executive Power", Chicago Law School: Public Law and Legal Theory Working Paper Series, Paper No: 133.

Bozlağan, R. (2016), Türk Tipi Başkanlık, Hayat Yayın, İstanbul.

Bruff, H. H. (1979), "Presidential Power and Administrative Rulemaking", The Yale Law Journal, C.88, S.3, ss. 451-508.

Can, O. (2017), “Anayasa Değişikliği Teklifine Dair Değerlendirme”, [çevrimiçi], http://www.sosyalbilimler. org/osman-can-kaleme-aldi-anayasa-degisikligi-teklifine-dair-degerlendirme/, (10 Ocak 2017).

Cengiz, B. (2017), “ABD Başkanlık Sisteminde Başkanın Yetkileri”, [çevrimiçi], http://www.dogrulukpayi. com/bulten/5818alf213d57, (21 Şubat 2017).

Chu, V. S. and Garvey, T. (2014), Executive Orders: Issuance, Modification, and Revocation, Congressional Research Service Report, [çevrimiçi], https://fas.org/sgp/crs/misc/RS20846.pdf, (28 Şubat 2017).

Contrubis, J. (1999), Executive Orders and Proclamations, CRS Report for Congress.

Çolak, Ç. D. ve Uzun, A. (2017), “Türk Siyasal Hayatında Başkanlık Sistemini Gündeme Getiren Liderler: Türkeş, Demirel, Özal ve Erdoğan”, Uluslararası Sosyal Araştırmalar Dergisi, C.10, S.50, ss. 196-214.

Deering, C. J. and Maltzman, F. (1999), "The Politics of Executive Orders: Legislative Constraints on Presidential Power”, Political Research Quarterly, C.52, S.4, ss. 767-783.

Erdoğan, M. (2013), "Başkanlık Sistemi, Demokrasi ve Türkiye”, Yeni Türkiye Dergisi, C.9, S.51, ss. 542547.

Fisher, L. (1995), Presidential War Power, University Press of Kansas, Lawrence.

Gözler, K. (2016), Devlet Başkanları: Bir Karşılaştırmalı Anayasa Hukuku İncelemesi, Ekin Yayınları, 2.Bask1, Bursa.

Gözler, K. (2016), "Elveda Kuvvetler Ayrılı̆̆ı, Elveda Anayasa: 10 Aralık 2016 Tarihli Anayasa Değişikliği Teklifi Hakkında Bir Eleştiri”, [çevrimiçi], www.anayasa.gen.tr/elveda-anayasa-v2.pdf, (23 Aralık 2016).

Gözler, K. (2017), Elveda Anayasa: 16 Nisan 2017’de Oylayacağımı Anayasa Değişikliği Hakkında Eleştiriler, Ekin Yayınları, Bursa.

King, G. and Ragsdale, L. (1988), The Elusive Executive: Discovering Statistical Patterns in the Presidency, CQ Press, Washington.

Köker, L. (2017), "Başkanlık Sistemine Dair Doğru Sanılan Yedi Yanlış”, [çevrimiçi], http://www. diken. com.tr/baskanlik-sistemine-dair-dogru-sanilan-yedi-yanlis/, (19 Şubat 2017). 
Krause, G. A. and Cohen. D. B. (1997), "Presidential Use of Executive Orders: 1953-1994", American Politics Quarterly, S.25, ss. 458-481.

Kuzu, B. (2017), Her Yönü ile Başkanlık Sistemi: Yeni Sistem Cumhurbaşkanlığı Modelimiz, Babıali Kültür Yayınları, İstanbul.

Küçük, A. (2016), “AK Parti'nin Başkanlık Sistemi Modelinin ABD’deki Başkanlık Sistemi Modelinden Farklı1ık Arz Eden Yönleri”, Kırıkkale Üniversitesi Sosyal Bilimler Dergisi, C.6, S.1, ss. 25-63.

Mayer, K. R. (1999), "Executive Orders and Presidential Power”, The Journal of Politics, C.61, S.2, ss. 445466.

Moe, T. M. (1993), 'Presidents, Institutions, and Theory', Researching the Presidency (Eds: George Edwards, John Kessel and Bert Rockman), University of Pittsburgh Press, Pennsylvania, ss. 337-386.

Nomer, M. (2013), ABD Başkanlık Sisteminde Başkanın Yetkileri, XII Levha Yayınları, İstanbul.

Özbudun, E. (1993), Türk Anayasa Hukuku, Yetkin Yayınc1lık, 3.Bask1, Ankara.

Özbudun, E. (2013), “Hükümet Sistemi Tartışmaları”, Yeni Türkiye Dergisi, C.9, S.51, ss. 205-213.

Peltason, J. W. (2017), “About America: The Constitution of the United States of America with Explanatory Notes”, [çevrimiçi], https://photos.state.gov/libraries/amgov/30145/publications-english/constitution.pdf, (28 Şubat 2017).

Pious, R. M. (1979), The American Presidency. Basic Books, New York.

Ragsdale, L. and Theis J. J. (1997), "The Institutionalization of the American Presidency, 1924-92", American Journal of Political Science, S.41, ss. 1280-1318.

Shull, S. A. (1997), Presidential-Congressional Relations: Policy and Time Approaches, University of Michigan, Ann Arbor.

Taşdöğen, S. (2016), “Cumhurbaşkanlığ1 Kararnameleri”, Ankara Üniversitesi Hukuk Fakültesi Dergisi, C.65, S.3, ss. 937-966.

Teziç, E. (2013), "Başkanlık Rejimini Anlamak”, Yeni Türkiye Dergisi, C.9, S.51, ss. 366-371.

The Constitution of the United States, [çevrimiçi], https://www.usconstitution.net/const.pdf, (28 Şubat 2017).

Türkiye Cumhuriyeti Anayasasında Değişiklik Yapılması Hakkında Kanun Teklifi, [çevrimiçi], http://www2. tbmm.gov.tr/d26/2/2-1504.pdf., (21 Aral1k 2016).

Url, “ABD Başkanında Bile Bu Yetki Yok!”, [çevrimiçi], http://www.aksam.com.tr/guncel/ abd-baskanindabile-bu-yetki-yok--151568h/haber-151568, (17 Şubat 2017).

Url, "Başkanlı̆̆ın Yüzde Doksanı ABD Modeli Gibi Olacak", [çevrimiçi], http://www.haberturk.com lgündem /haber/1317065-baskanligin-yuzde-90i-abd-modeli-gibi-olacak, (18 Şubat 2017).

Url, [çevrimiçi], http://www.presidency.ucsb.edu/, (20 Eylül 2017).

Url, “Obama'nın Göçmenlik Kararnamesi Ne Getiriyor?”, [çevrimiçi], http://amerikabulteni.com/2014/11/22/ obamanin-gocmenlik-kararnamesi-ne-getiriyor/, (21 Şubat 2017). 